\title{
Anti-WebShell PHP Backdoor Scanner pada Linux Server
}

\author{
Christian Ronaldo Sopaheluwakan ${ }^{\mathrm{a}, 1^{*}}$ dan Dian Widiyanto Chandra ${ }^{\mathrm{a}, 2}$ \\ ${ }^{a}$ Universitas Kristen Satya Wacana, Jl. Diponegoro 52-60, Salatiga, 50711, Indonesia \\ ${ }_{1}^{1} 672016226 @$ student.uksw.edu; ${ }^{2}$ dian.chandra@uksw.edu \\ * corresponding author
}

\begin{abstract}
INFORMASI ARTIKEL
\section{ABSTRAK}

Dikirim : 29 Juni 2020

Diulas : 23 Juli 2020

Direvisi : 30 Juli 2020

Diterbitkan : 27 Agustus 2020

Kata Kunci:

Anti-Web Shell

Deteksi Backdoor

Backdoor Shell

Keamanan Jaringan

Server Linux

Backdoor atau yang biasa juga dikenal dengan istilah web shell merupakan salah satu kode yang digunakan hacker untuk maintaining access sistem secara ilegal. Beberapa program seperti Anti Web-Shell, PHP Backdoor Scanner yang bisa didapatkan secara gratis untuk menangani web shell. Namun program-program tersebut memiliki database signature yang tidak diperbaharui untuk menghadapi PHP backdoor / Shell saat ini. Sehingga diperlukan program Anti Web-Shell kontemporer yang mampu menghadapi shell backdoor saat ini. Penelitian ini menggunakan metode eksperimen dengan acuan penelitian serupa sebelumnya dan diimplementasikan langsung ke dunia industri profesional keamanan siber. Dengan memperkaya signature kamus Regex dan String Array Matching Program Anti Web-Shell yang sudah diaktualisasi dapat mendeteksi backdoor lebih banyak dibandingkan program serupa yang sudah lampau. Hasil dari penelitian ini adalah berupa web application software dalam ekstensi PHP. Aplikasi dapat meminimalisir $100 \%$ terjadinya false positives serta lebih cepat 2 kali lipat dalam memindai files karena lebih spesifik dalam melakukan heuristic anlysys scan.

\section{Keywords:}

Anti-Web Shell

Backdoor Scanner

Backdoor Shell

Network Security

Linux Server

ABSTRACT

Backdoor or commonly also known as web shell is one of the malicious software that hackers use to maintain access systems that they have entered. Relatively few programs like Anti Web-Shell, PHP Backdoor Scanner circulating on the Internet, and can be obtained free of charge to deal with the issues above. But most of these programs have no actual database of signature behavior to deal with PHP backdoor / Shell nowadays. Then comes the contemporary Anti WebShell program that can deal with today's backdoor shell. This study uses an experimental method concerning previous similar studies and is implemented directly into the world of cyber security professional industries. By enriching the Regex dictionary signature and String Array Matching the actualized Anti WebShell program can detect more backdoor than similar programs that have existed in the past. The results of this study are in the form of a web application software in PHP extension. The application can minimize $100 \%$ of false positives and is twice as fast in scanning files because it is more specific in heuristic analysis scan.
\end{abstract}

This is an open access article under the $\underline{\mathrm{CC}-\mathrm{BY}-\mathrm{SA}}$ license.

\section{Pendahuluan}

Berdasarkan data dari defaced websites (zone-h.org), perhari ada belasan sampai puluhan situs pemerintah Indonesia (dengan domain *.go.id) yang berhasil diretas. Proses peretasan ini tidak diketahui oleh pemilik situs tersebut bahkan dalam waktu yang sangat lama pengelola website tersebut tidak menyadari jika websitenya diretas[1]. Maraknya aksi "Deface" atau "Pembajakan" yang dilakukan para Hacker luar negeri dan juga dari dalam negeri terhadap situs-situs pemerintahan, organisasi, polisi, tentara, dan bahkan penyedia provider Internet besar Indonesia. Masalah seperti ini merupakan hal yang sangat miris dan patut dipertanyakan kredibilitasnya ketika provider layanan Internet di Indonesia bisa terkena aksi usil dari Hacker yaitu "Deface". Hal ini menunjukkan bahwa kesadaran akan dunia IT Security di negara Indonesia masih rendah dan kurangnya SDM praktisi IT Security itu sendiri. Masalah ini merupakan hal yang perlu diperhatikan dan diutaman ke depannya untuk pengelolaan website yang lebih baik khususnya dalam permasalahan Cyber Security.

"Deface" merupakan salah satu kegiatan merubah tampilan suatu website baik itu halaman utama, index file, atau pun halaman lain yang masih terikat dalam satu URL dengan website tersebut[2]. Kegiatan ini sendiri kerap disalahgunakan oleh para Hacker untuk tujuan bersenang-senang semata[3]. Aksi ini memerlukan yang 
disebut gaining access[4],[5]. Pada umumnya Hacker memanipulasi privileges access untuk gaining access tersebut dengan cara menanamkan backdoor access yang ditanamkan dengan berbagai macam cara dan kreatifitas sang Hacker[6][7]. Faktanya sekarang ini Backdoor paling banyak dibuat dengan bahasa pemrograman PHP[8],[9]. Relatif sedikit Softwares serupa Anti Web-Shell, PHP Backdoor Scanner yang beredar di Internet \& Bisa didapatkan secara free untuk menangani issues masalah diatas[10]. Tetapi kebanyakan dari softwares tersebut sudah tidak up to date database behaviour signature-nya untuk menghadapi PHP backdoor I Shell jaman sekarang[11].

Penelitian terkait keamana server yaitu yang berjudul "Analisis Pendeteksian dan Pencegahan Serangan Backdoor Pada Layanan Server". Penelitian ini menggunakan Metode Eksperimen, membahas tentang backdoor serta cara melakukan tindakan preventifnya. Backdoor adalah cara yang digunakan untuk masuk ke dalam sistem tanpa sepengetahuan administrator. Backdoor bertujuan untuk mempermudah memasuki sistem itu kembali jika jalan yang sudah dibuat dengan exploit telah ditutup oleh administrator. Maka dibuatlah simulasi yang saling berhubungan yang bertujuan untuk melakukan analisis terhadap Backdoor yang menggunakan IDS / IPS Snort [12]. Penelitian selanjutnya yaitu "Implementasi Backdoor Scanner Tool Menggunakan Metode Carving File Pada Server Codepolitan”, lebih ditujukan untuk backdoor dalam bentuk source code PHP dan Image yang memiliki ekstensi jpg, png menggunakan metode carving file, pendekatan string dan REGEX. Adapun tujuan penelitian ini dilakukan untuk merancang sebuah tools pemindai yang dapat mempermudah admin menemukan backdoor di dalam sebuah server[10].

Penelitian selanjutnya yaitu "Basic Static Code Analysis untuk Mendeteksi Backdoor Shell pada Web Server", lebih fokus dalam scenario pengujian deteksi menggunakan system yang dibangun \& Skenario pengujian deteksi menggunakan PHP Shell Detector[9]. Penelitian selanjutnya yaitu "Sistem Keamanan Jaringan Mendeteksi Backdoor Untuk Menemukan Celah Dan Exploits Pada Web Server Menggunakan Teknik IDS (Intrusion Detection System)", penelitian ini membuktikan bahwa Teknik IDS (Intrusion Detection System) dapat digunakan untuk membantu proses deteksi file backdoor pada web server untuk menemukan celah dan exploits. Dengan teknik IDS berbasis signature, setiap file yang dideteksi akan dicocokan dengan data signature[13]. Adapun penelitian lain yang berjudul "Analisis dan Deteksi Malware Menggunakan Metode Malware Analisis Dinamis dan Malware Analisis Statis". Penelitian ini menjelaskan bahwasannya : Ada dua tipe analisis dalam melakukan analisis pada malware yaitu dengan analisis statis (analisa kode) dan analisis dinamis [8].

Berdasarkan penelitian-penelitian sebelumnya yang relevan dengan backdoor salah satu cabang substansi dari Cyber Security dapat disimpulkan bahwa Backdoor selalu berkembang. Pergerakannya dinamis, layaknya pembuat Virus \& Anti-Virus. Jika ada Virus baru yang release maka harus dibuat serum yang baru sebagai penangkalnya. Maka dari itu penelitian ini hadir untuk menjawab hal tersebut. Perbedaannya adalah penelitian ini menganalisa versi software anti backdoor sejenis sebelumnya, mengkolaborasikan teori penelitian serupa sebelumnya untuk menyempurnakannya menjadi versi baru yang lebih Mutakhir, Optimal, Efektif, \& Efisien, serta fitur yang lebih spesifik. Agar tidak hanya menjadi kesan omong-kosong belaka, penelitian ini nantinya akan diimplementasikan langsung di LAB PT. Datacomm Diangraha yang menggunakan environtment Linux Server yang mendukung Platform PHP Server. Software Anti Web-Shell, PHP Backdoor Scanner yang berjalan pada Platform PHP Server yang pada umumnya digunakan untuk Linux Server ini akan dibuat lebih sempurna serta aktual dengan menyesuaikan riset survey berbagai macam backdoor yang beredar di Internet recently. Penelitian ini diharapkan akan membantu SysAdmin Server / Administrator Website dalam melakukan maintaining scanning rutin demi prosedur security assessment mereka. Dan apabila menggunakan Software Anti Web-Shell (AWS) yang sudah dirombak, diperbaharui, serta diberi bumbu improvement tambahan dari hasil penelitian yang menyesuaikan dengan jaman sekarang ini, harapannya membuat presentase angka keamanan pemilik atau pengelola website serta Server relatif semakin tinggi kiblat tingkat keamanannya dari serangan penanaman PHP backdoor oleh Hacker / Attacker jaman sekarang.

\section{Metode}

Dalam penelitian ini penulis menerapkan Metode Eksperimen. Metode Eksperimen merupakan metode yang paling banyak dipilih dan paling produktif dalam penelitian. Apabila dilakukan dengan baik, studi eksperimental menghasilkan bukti yang paling benar terkait dengan hubungan sebab-akibat[12]. Menurut Gay (1981) dalam Emzir (2013:63) menyatakan bahwa penelitian eksperimental merupakan satu-satunya metode penelitian yang dapat menguji secara benar hipotesis menyangkut hubungan kasual (sebab-akibat). Langkahlangkah metode eksperimen dapat dilihat pada Gambar 1. 


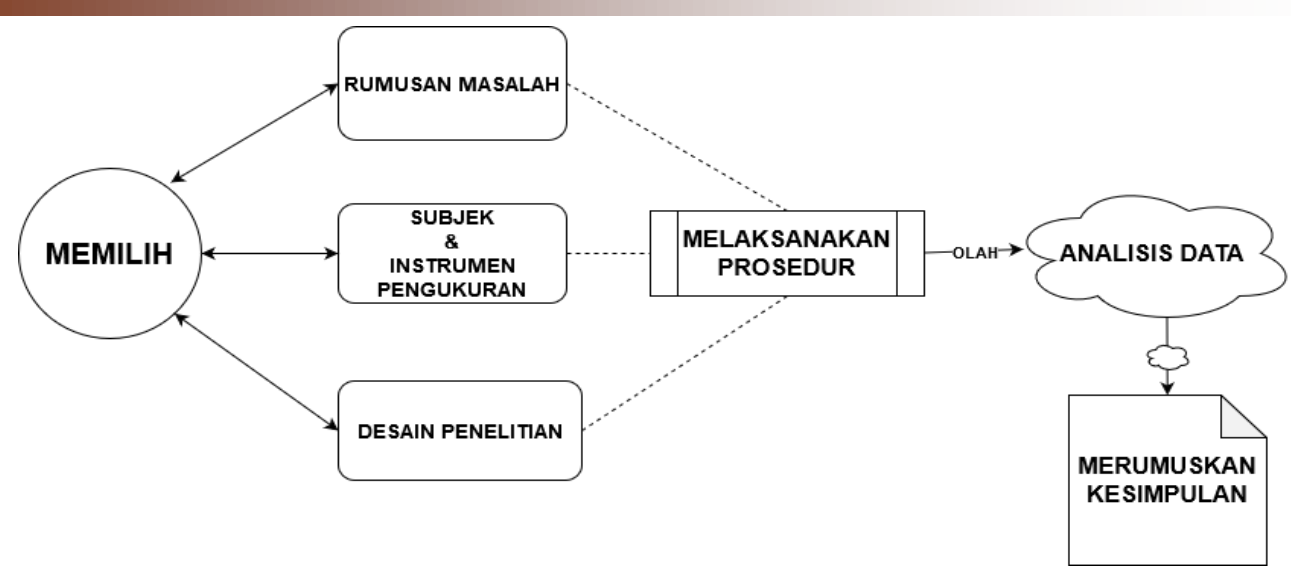

Gambar 1. Flowchart Pengimplikasian Metode Eksperimen

Berikut design topologi simulasi pada internal LAB Datacomm dapat dilihat pada Gambar 2.

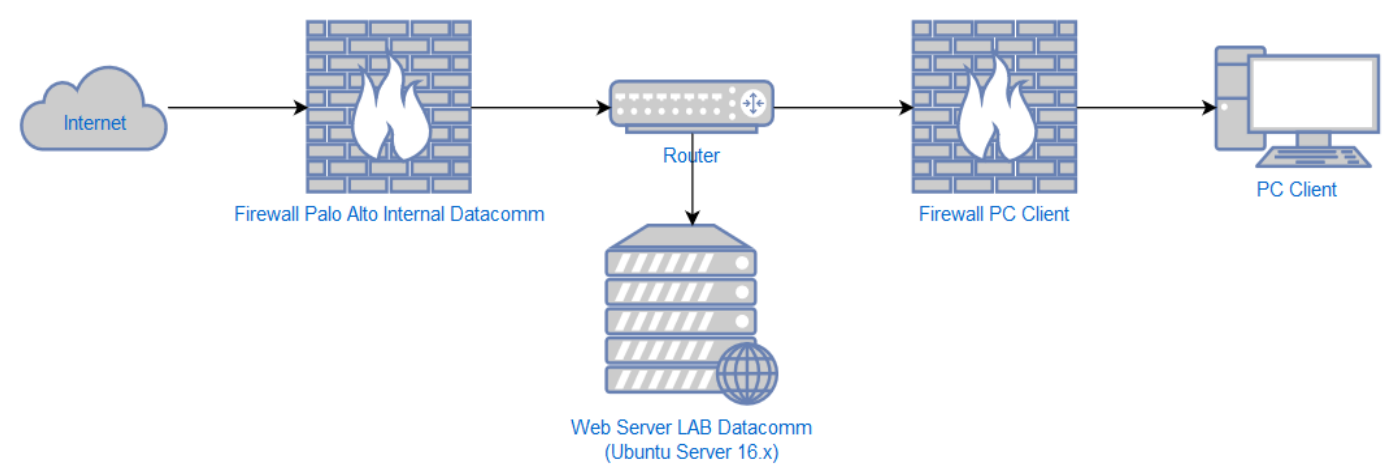

Gambar 2. Web Server Machine LAB Datacomm

\section{Hasil dan Pembahasan}

Flow Chart Software Lampau dapat dilihat pada Gambar 1.

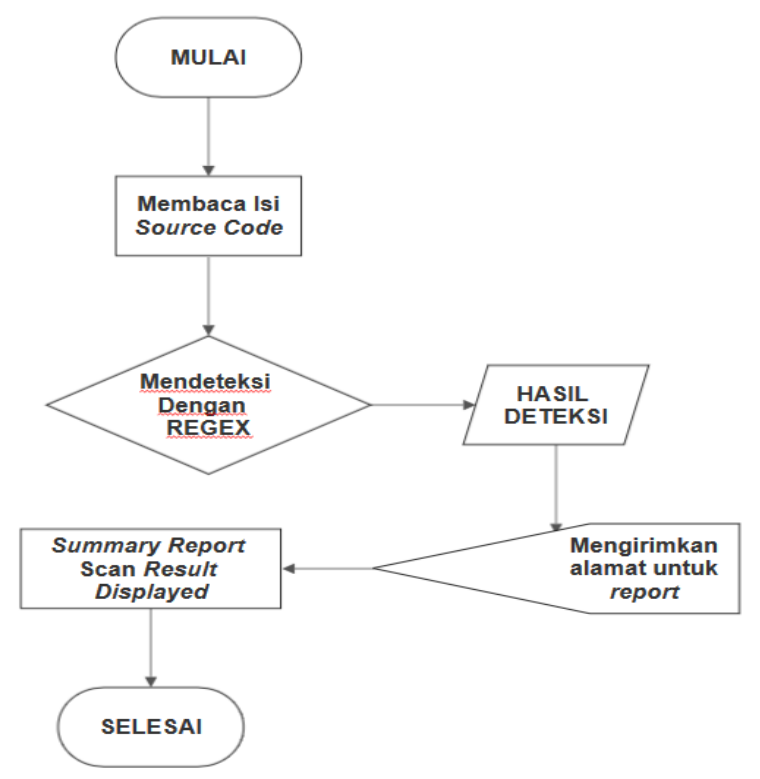

Gambar 3. Flow Chart Software Lampau 
Analisa Software Lampau:

Pada software lampau, modul scanning mengambil masukan data berupa files yang terdapat pada semua directory membaca source code masing-masing files secara membabi buta (massive scan), hal ini dapat memberatkan server[15]. Dilanjutkan dengan pencocokan PHP Regex yang relatif tidak di update keyword signature untuk backdoors dengan kondisi aktual di jaman yang sekarang ini. Hasil deteksi akan muncul, tentu saja presentase false positive relatif tinggi, karena kamus Regex yang tidak di update tersebut sangat minim (Bisa dilihat highlight kuning pada Source Code diatas). Lalu Software lampau ini akan mengirimkan alamat untuk report yang akan disuguhkan dalam bentuk .html sederhana (result-scanner-lawas.html). Kemudian jika dibuka akan menampilkan ringkasan hasil pemindaian berkas-berkas yang kemungkinan backdoor infected atau safe. Namun di header title output scan result meninggalkan sebuah pesan yaitu "Be Carefull w/False Positive", yang intepretasinya yakni pengguna di wanti-wanti untuk lebih menyaring lagi secara manual dan jangan percaya begitu saja dengan Software ini. Walaupun Software ini bersifat passive preventive, tetapi ia tidak lancang untuk melakukan keputusan Modify atau Delete. Yang mana hal ini akan dikembalikan oleh keputusan sang User.

Penyempurnaan Software Anti-WebShell:

Belajar dari analisa di atas, intisari masalahnya adalah menambahkan kamus Regex yang lebih up to date untuk signature backdoors pada jaman sekarang. Tentunya dengan ikut serta mengkombinasikan beberapa metode selain Regex yaitu; Anomaly Checks Techniques; Whitelisting \& Blacklisting Techniques[16]. Akan dikemas dengan menggunakan bahasa PHP, Based GUI (Grapical User Interface). Memberikan kesan More User Friendly pada pengguna software kelak. Serta akan dibuat compitable dengan seluruh versi distro Linux. Flow Chart Software Anti-WebShell dapat dilihat pada Gambar 4.

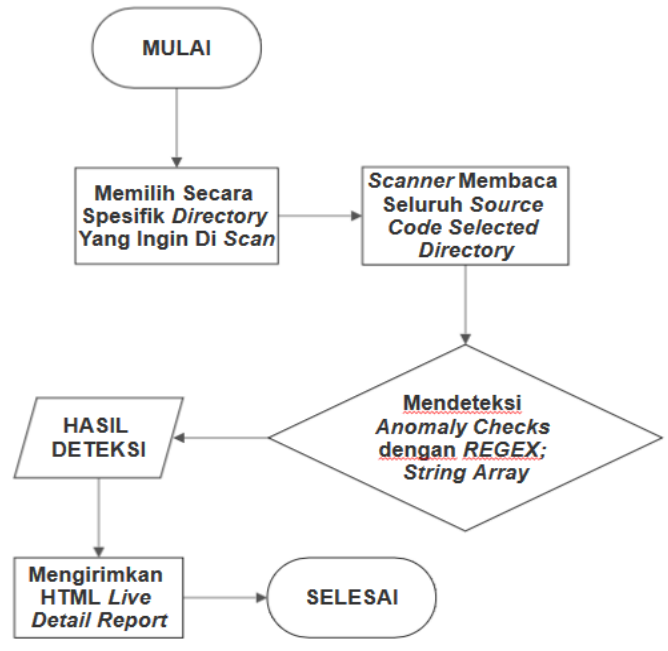

Gambar 4. Flow Chart Software AWS

Komparasi Software Lampau dengan Software Anti-WebShell yang telah dibuat akan diimplementasikan pada salah satu server LAB PT Datacomm Diangraha, yang menggunakan sistem operasi Ubuntu Server 16.04.6 LTS. Diakses secara local (DMZ) tetapi Integrated dengan IP WAN Datacomm yakni 103.252.50.200

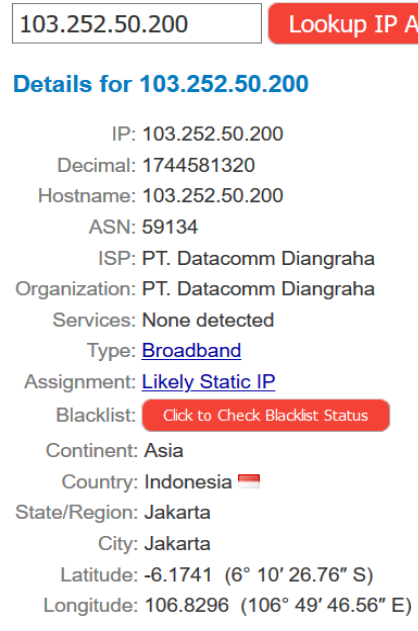




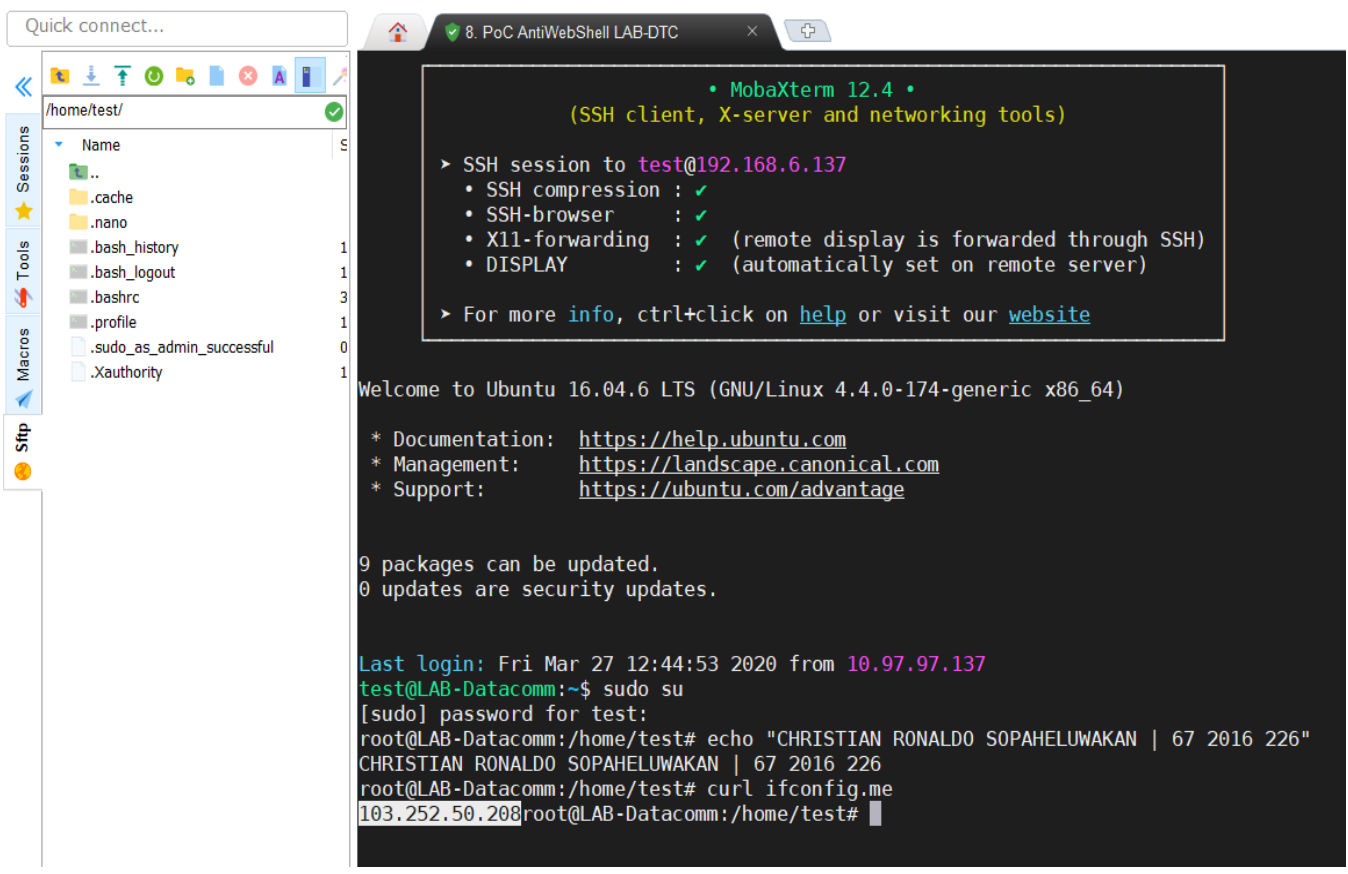

Gambar 5. Server LAB Datacomm

Jika melihat Gambar 5. Server LAB Datacomm maka terdapat details SSH Sessions to test@192.168.6.137 dilanjutkan dengan akses IP tersebut secara lokal di browser.

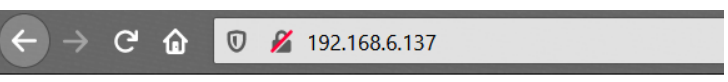

\section{Index of /}

\begin{tabular}{|c|c|}
\hline Name & Last modified Size Description \\
\hline ? aws.php & $2020-03-2717: 195.3 \mathrm{~K}$ \\
\hline Qclean/ & $2020-03-2717: 57$ \\
\hline @infected/ & $2020-03-2717: 57$ \\
\hline 澄 result-scanner-lawas.htm & $12020-03-3017: 471.1 \mathrm{~K}$ \\
\hline scanner_lawas.php & $2020-03-3017: 463.1 \mathrm{~K}$ \\
\hline
\end{tabular}

Apache/2.4.18 (Ubuntu) Server at 192.168.6.137 Port 80

Gambar 6. Index of Server

Gambar 6 merupakan tampilan Public Index Of Server yang berjalan di Web Server salah satu Machine LAB Datacomm yang mana bisa dilihat Apache/2.4.18 menunjukkan Software Web Server yang digunakan, 192.168.6.137 merupakan IP Local dari salah satu Machine LAB tersebut, dan port 80 adalah default Port pengoneksian ke Web Server. Selain itu terdapat isi root directory dari Web Server yang meliputi files; aws.php, scanner_lawas.php, result-scanner-lawas.html serta Folders /clean/ serta /infected/ dan bisa dilihat Last Modified, Size, serta Description dari masing-masing data tersebut.

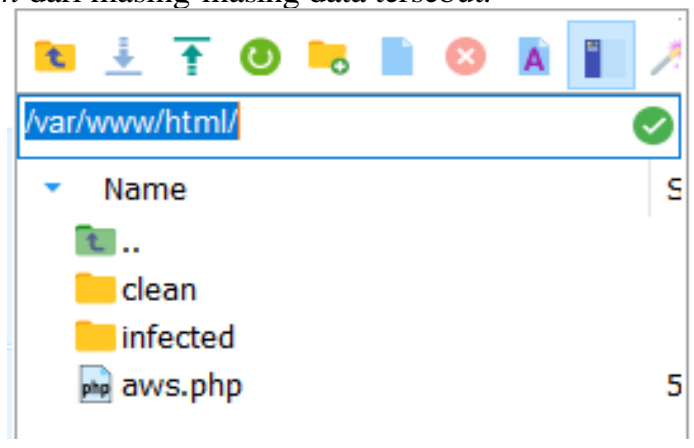

Gambar 7. Root Directory SysAdmin Perspective 
Gambar 7 diambil dari sisi SysAdmin yang sedang manage server. /var/www/html/ merupakan Root Directory Default Web Server Apache. SysAdmin membuat folder /clean/ untuk simulasi suatu directory yang memang clean \& Safe tanpa backdoor infected. Tetapi sebaliknya folder /infected/ merupakan simulasi suatu directory yang sudah terinfeksi backdoor \& Ancaman lain yang memungkikan untuk harming the system of the server. Serta Software Anti-WebShell yang mana adalah aws.php telah dibuat atau diunggah ke dalam Apache Web Server.

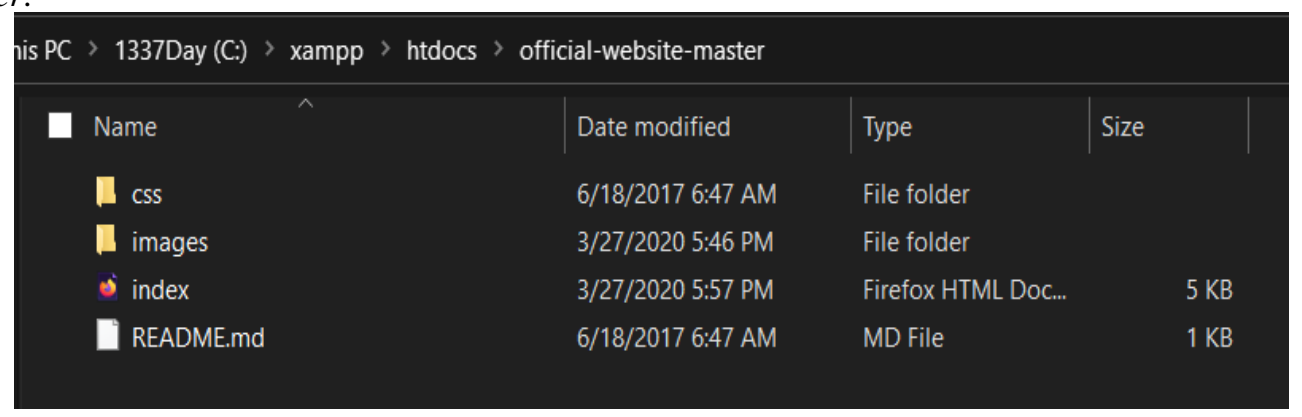

Gambar 8. Source Code Sample Portal Website

Gambar 8 merupakan source code dari portal website sederhana yang dibuat HTML5, full static. Dalam folder /clean/ \& /infected/ akan diunggah source code portal websites ini sebagai sample simulasi penelitian.

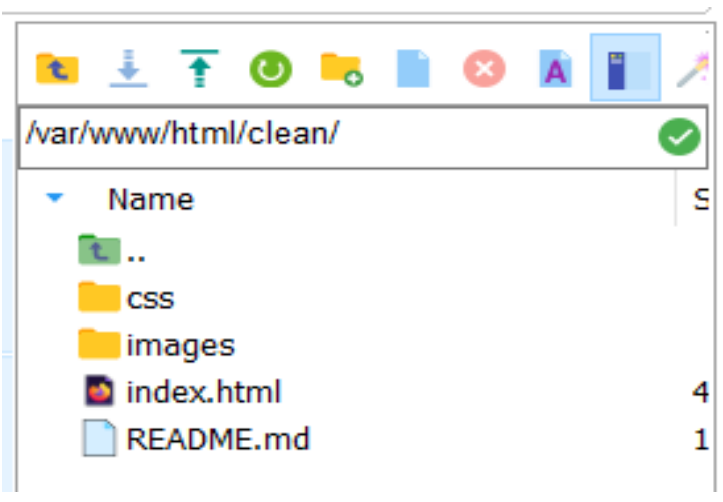

Gambar 9. Clean Folder

Gambar 9 menampilkan folder /clean/ ini merupakan folder yang belum terinfeksi backdoor. Semua Source Code Original dari portal website sederhana yang telah dibuat di atas diunggah ke /var/www/html/clean/.

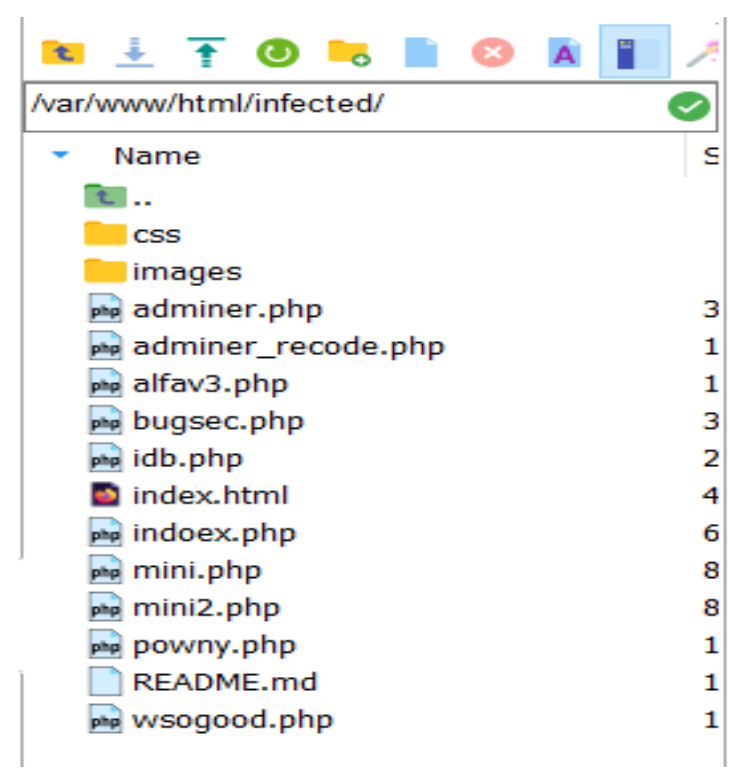

Gambar 10. Infected Folder 
Gambar 10 menampilkan folder /infected/ ini merupakan folder yang sudah terinfeksi dengan banyak type backdoors. Source code original dari portal website sederhana yang dibuat sudah terkontaminasi dengan berbagai macam 10 type backdoors yang tertanam di /var/www/html/infected/ yakni; adminer.php, adminer_recode.php, alfav3.php, bugsec.php, idb.php, indoex.php, mini.php, mini2.php, powny.php, wsogood.php yang mana sample backdoors ini di ambil dari Internet, Komunitas Cyber Underground, maupun ada beberapa sample backdoor hasil modifikasi yang diambil langsung dari praktisi Cyber Security.

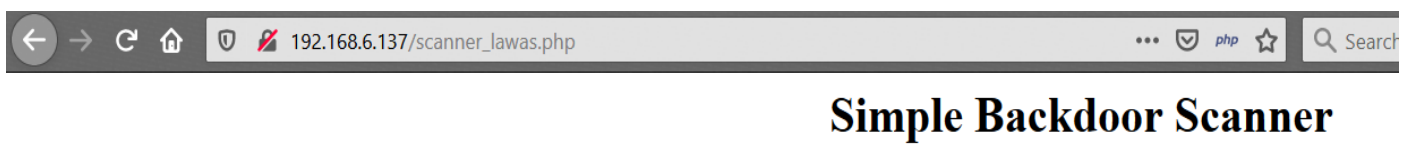

Note : Be carefull w/ False Positive

/aws.php $\Rightarrow>$ Found (file_get_contents)

/clean/README.md $=>$ Safe

/clean/css/style.css $=>$ Safe

/clean/images/header-logo.png $=>$ Safe

/clean/images/redhat.png $=>$ Safe

.clean/images/teguh-thumb.png $=>$ Safe

.clean/index.html $=>$ Safe

.infected/README.md $=>$ Safe

./infected/adminer.php $=>$ Found (base64_encode, base64_decode, fwrite, str_replace, file_get_contents, substr)

./infected/adminer_recode.php $=>$ Found (base64_decode, eval, gzinflate, str_rot13, file_get_contents)

.infected/alfav3.php $=>$ Found (substr)

./infected/bugsec.php $=>$ Safe

Gambar 11. Scan Result with Old Software

Software lampau sejenis (Simple Backdoor Scanner) yang didapatkan secara free di Internet melakukan scanning secara membabi buta (massive scan) tidak spesifik. Dan alhasil hanya mampu memprediksi ancaman 4 backdoors saja yang ditampilkan pada Gambar 11, yakni; aws.php, adminer.php, adminer_recode.php, alfa3.php dan terdapat note bahwa masih banyak presentase kemungkinan False Positive.
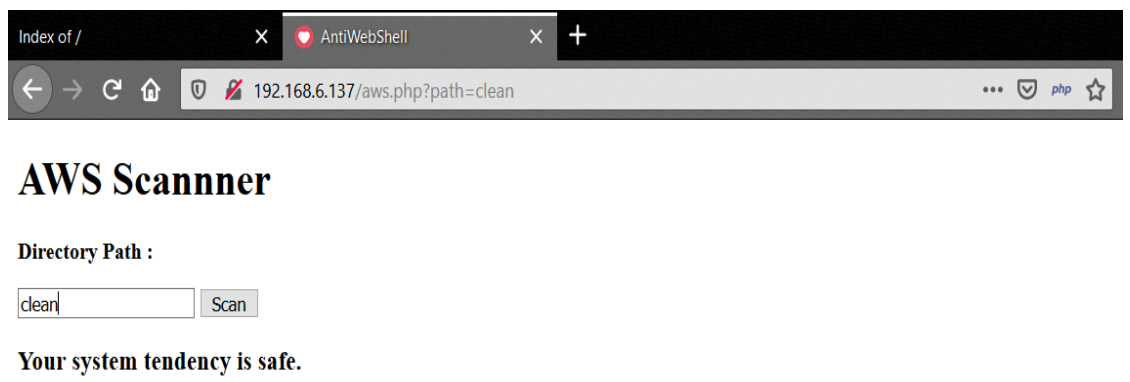

Gambar 12. Scan /clean/Folder with AWS Software

Gambar 12 menampilkan software Anti-WebShell (AWS) melakukan scanning secara spesifik ke Directory Path /clean/ dan AWS system result mencoba menyatakan prediksi dari Software AWS ini adalah "Your system tendency is safe". Deklarasi tersebut menyatakan tendensi dari folder /clean/ berdasarkan presentase aman dari infeksi backdoor. Karena sesuai skenario awal yakni folder /clean/ merupakan original source code portal website HTML5, Full Static, tanpa terkontaminasi backdoors yang tertanam. 


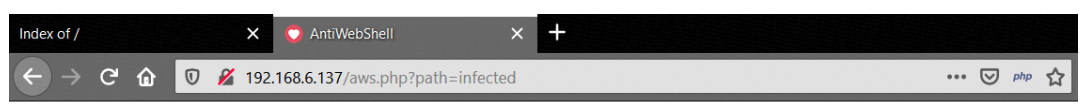

\author{
AWS Scannner \\ Directory Path :

infected $\quad$ Scan \\ 10 Backdoor detected : \\ Scan results on vendor folder and base64_decode functions or any CMS may be FALSE POSITIVE \\ $/ \mathrm{var} / \mathrm{www} / \mathrm{htm} / \mathrm{infected} / \mathrm{adminer}$.php \\ /var/www/html/infected/adminer_recode.php \\ /var/www/html/infected//alfav3.php \\ Nar wwwhthlinected/bugsec.p \\ (var/www/htm/infected/idb.php \\ var/www/htm/infected/indoex.php \\ $/ \mathrm{var} / \mathrm{www} / \mathrm{htm} / \mathrm{infected} / \mathrm{mini}$.php \\ /var/www/html/infected/pownyph \\ /var/www/html/infected/wsogood php
}

Gambar 13. Scan /infected/ Folder with AWS Software

Gambar 13 menampilkan software Anti-WebShell (AWS) melakukan scanning secara spesifik ke Directory Path linfected/ dan AWS system result menyatakan "10 Backdoor detected!", 10 type backdoors ini adalah semua backdoors yang sudah disebutkan di skenario sebelumnya yakni; adminer.php, adminer_recode.php, alfav3.php, bugsec.php, idb.php, indoex.php, mini.php, mini2.php, powny.php, wsogood.php yang semua berada di /var/www/html/infected/ sesuai skenario, directory /infected/ ini memang berisi original source code portal website sederhana dari HTML5, Full Static akan tetapi kondisinya terkontaminasi oleh berbagai macam backdoors tertanam. Selain itu terdapat alert berupa "Scan results on vendorfolder and base64_decode functions or any CMS may be FALSE POSITIVE" yang merupakan usaha dari Software AWS mengingatkan akan gejala False Positive yang disebabkan oleh beberapa fungsi yang dianggap mencurigakan dari Content Management System (CMS) serta fungsi-fungsi mencurigakan lain seperti base64_decode.

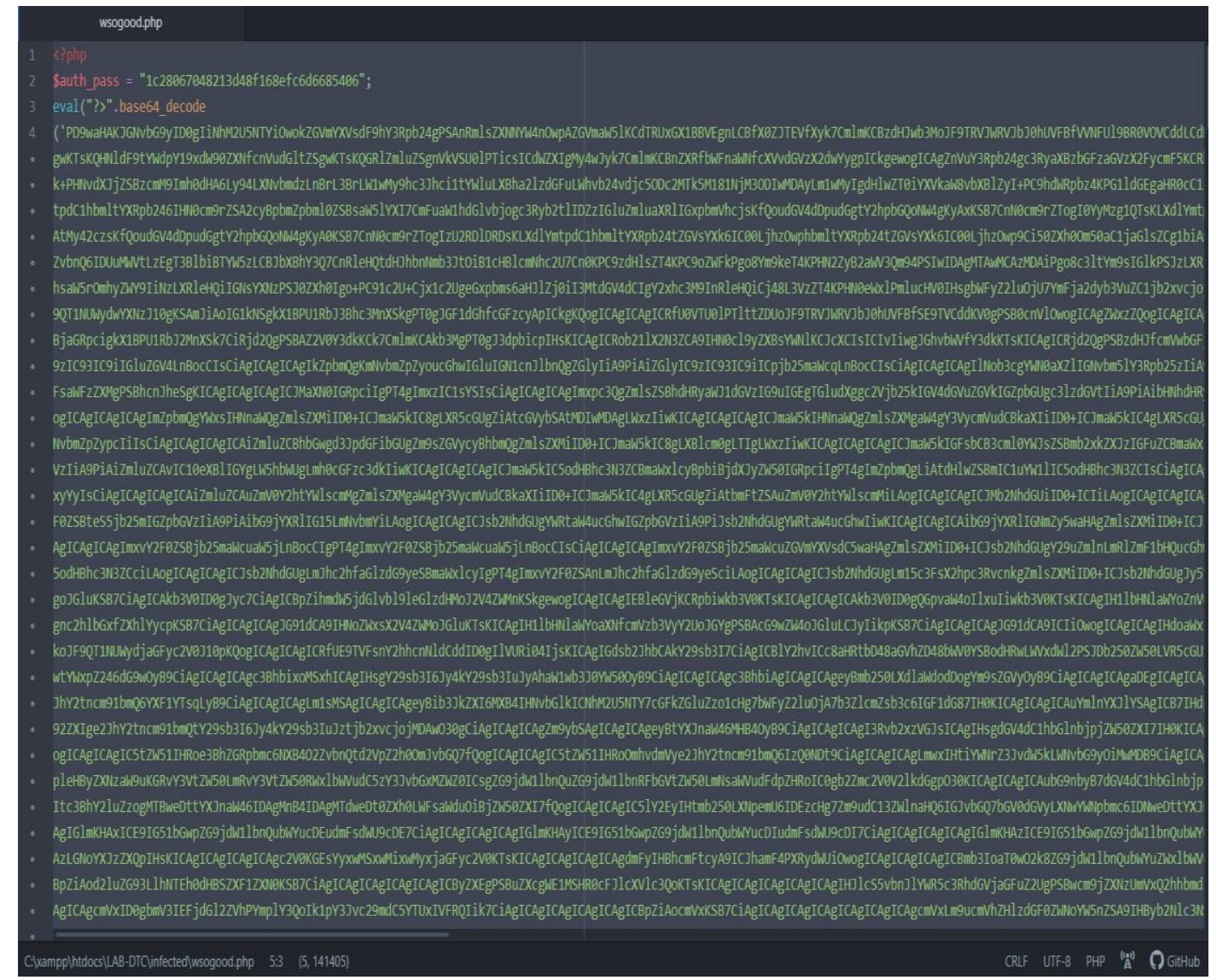

Gambar 14. Source code wsogood.php 
Gambar 14 menunjukkan contoh Source Code dari salah satu backdoors pada simulasi yang telah dilakukan, yaitu wsogood.php dengan full base64_encode. Rata-rata signature yang ditunjukkan behaviour backdoors yakni selalu menggunakan base64_decode. Maka dari itu mudah saja bagi AWS untuk memindai dan declare file wsogood.php sebagai backdoor.

\begin{tabular}{|c|c|c|c|c|c|c|c|c|}
\hline Status & Method & Domain & File & & Cause & Type & Transferred & Size \\
\hline 200 & GET & O localhost:8080 & scanner_lawas.ph & & document & $\mathrm{html}$ & $2.29 \mathrm{~KB}$ & $2.01 \mathrm{~KB}$ \\
\hline 404 & GET & localhost:8080 & faviconico & & img & html & cached & $1.03 \mathrm{~KB}$ \\
\hline ৫ & quests & 3.04 KB / 2.29 KB transferred & Finish: $26.04 \mathrm{~s}$ & DOMContentLoaded: $25.71 \mathrm{~s}$ & load: $25.74 \mathrm{~s}$ & & & \\
\hline
\end{tabular}

Gambar 15. Waktu Scan Software Lampau

Gambar 15 menunjukkan aktifitas realtime software lampau mengeksekusi pemindaian massive scan secara langsung pada root directory dan melakukan 2 request dengan method GET file yaitu: scanner_lawas.php \& favicon.ico yang masing-masing tipenya adalah document dan img. Waktu load yang dibutuhkan sampai scanner benar-benar selesai bekerja adalah $25.74 \mathrm{~s}$ dan DOMContentLoaded $25.71 \mathrm{~s}$.

\begin{tabular}{|c|c|c|c|c|c|c|}
\hline Status & Method & Domain & File & Cause & Type & Transferred \\
\hline 200 & GET & A localhost:8080 & aws.php?path=clean & document & html & $868 \mathrm{~B}$ \\
\hline 200 & GET & A img.icons8.com & hearts.png & img & png & cached \\
\hline
\end{tabular}

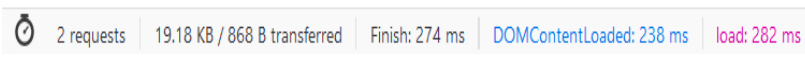

Gambar 16. Waktu Scan AWS @clean

Gambar 16 menunjukkan aktifitas realtime software AWS mengeksekusi pemindaian secara spesifik pada folder/clean/ dan melakukan 2 request dengan method GET file yaitu: aws.php?path=clean \& hearts.png yang masing-masing tipenya adalah document dan img. Waktu load yang dibutuhkan sampai scanner benar-benar selesai memindai folder/clean/ hanya $282 \mathrm{~ms}$ dan DOMContentLoaded $238 \mathrm{~ms}$.

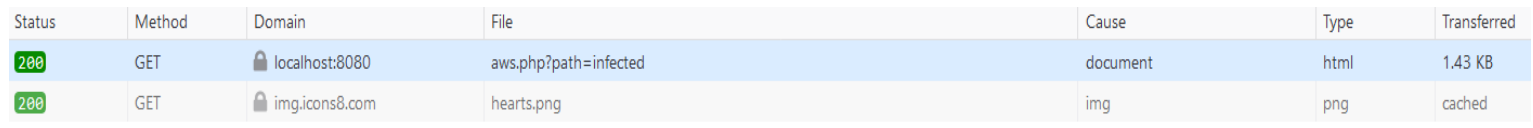

\begin{tabular}{ll|l|l|l|}
\hline ○ 2 requests 19.76 KB / 1.43 KB transferred & Finish: $635 \mathrm{~ms}$ & DOMContentloaded: $255 \mathrm{~ms}$ & load: $303 \mathrm{~ms}$
\end{tabular}

Gambar 17. Waktu Scan AWS @infected

Gambar 17 menunjukkan aktifitas realtime software AWS yang sedang mengeksekusi pemindaian secara spesifik pada folder /infected/ dan melakukan 2 request dengan method GET file yaitu: aws.php?path=clean \& hearts.png yang masing-masing tipenya adalah document \& img. Waktu load yang dibutuhkan sampai scanner benar-benar selesai memindai folder /clean/ hanya $303 \mathrm{~ms}$ dan DOMContentLoaded $255 \mathrm{~ms}$. Kesimpulan hasil analisis bisa di lihat pada Tabel 1 .

Tabel 1. Perbandingan Kinerja

\begin{tabular}{ccccc}
\hline No & $\begin{array}{c}\text { Programming } \\
\text { Languange }\end{array}$ & Software Name & Load Speed & Backdoor Detected \\
\hline 1 & PHP (CLI) & $\begin{array}{l}\text { Old, Simple Backdoor } \\
\text { Scanner }\end{array}$ & $25.74 \mathrm{~s}-25.71 \mathrm{~s}$ & 4 \\
\hline
\end{tabular}




\begin{tabular}{ccccc}
\hline No & $\begin{array}{c}\text { Programming } \\
\text { Languange }\end{array}$ & Software Name & Load Speed & Backdoor Detected \\
\hline 2 & PHP (GUI) & New, AWS Scanner & $282 \mathrm{~ms}-303 \mathrm{~ms}$ & 10 \\
\hline
\end{tabular}

Dengan kondisi sampel kasus yang sama software lama No. 1 menunjukkan rata-rata hasil finished scan diangka $25.74 \mathrm{~s}-25.71 \mathrm{~s}$ (second). Akan tetapi software baru No. 2 hanya membutuhkan waktu dua kali lipat lebih cepat yakni $282 \mathrm{~ms}$ - $303 \mathrm{~ms}$ (millisecond) karena pencarian custom folder yang bisa lebih spesifik dalam melakukan scanning files. Kemudian backdoor infected yang terdeteksi pada software lama adalah 4/10 (40\%) sedangkan software baru, AWS Scanner adalah 10/10 (100\%) dikarenanakan pengimplikasian heuristic analysys method dengan memanfaatkan fungsi grep findstr serta kamus Regex berkaitan dengan keyword backdoor yang aktual.

\section{Kesimpulan dan Saran}

Berdasarkan penelitian Anti-WebShell PHP Backdoor Scanner Pada Linux Server, dapat disimpulkan bahwa Sistem Software sejenis anti backdoor yang lampau (Simple Backdoor Scanner) ini sudah tidak up to date database signature, method dan kamusnya. Sistem Software AWS yang dibangun ini diperbaharui secara aktual serta dikemas lebih User Friendly, menyesuaikan perkembangan jaman Cyber Security, dengan menambah serta mengkombinasikan beberapa Teknik \& Metode baru serta memperkaya signature kamus Regex \& String Array Matching sehingga lebih optimal dan maksimal pemanfaatannya saat mencari infected backdoors pada web server. Adapun saran untuk penelitian serupa lebih lanjut yakni dapat menambahkan jenis Backdoors yang menggunakan bahasa pemograman lain selain PHP, contohnya ASP Backdoor. Kombinasikan dengan metode Text search Linux with grep or findstr Method sebagai variasi penyempurna scanner. Kemudian dapat juga menambahkan jenis file lain untuk melakukan scanning yang lebih lengkap terhadap seluruh files yang terdapat pada server. Lakukan penelitian lanjutan dengan algoritma machine learning substansi dari artificial intelligence untuk mengenali backdoors dengan proses yang lebih cepat serta full automasi.

\section{Ucapan Terima Kasih}

Penulis mengucapkan terima kasih banyak kepada PT. Datacomm Diangraha yang telah memberi dukungan dengan menyediakan perangkat, tempat dan akses jaringan untuk penelitian ini.

[1] T. S. Hartono, “Amankan Website Anda dari 'Defacement,"” 2011. https://tekno.kompas.com/read/2011/12/02/16352968/Amankan.Website.Anda.dari.Defacement?pag e=all\#page2 (accessed Apr. 13, 2019).

[2] U. Ite and H. Pidana, "Kejahatan Defecting :," vol. 3, pp. 143-159, 2015.

[3] C. Camilo, U. López, M. G. Peña, J. Luis, O. Quintero, and A. Estado, "Antidefacement - State of art," vol. 14, pp. 9-27, 2016, doi: 10.18046/syt.v14i39.2341.

[4] B. Ghozali, M. Teknik, I. Universitas, and A. Yogyakarta, "Mendeteksi Kerentanan Keamanan Aplikasi Website Menggunakan Metode Owasp ( Open Web Application Security Project ) untuk Penilaian Risk Rating,” pp. 264-275.

[5] J. Javier, B. Andrade, and D. Gan, "A Forensics Investigation into Attacks on Linux Servers."

[6] S. Kumar and D. Agarwal, "Hacking Attacks, Methods, Techniques And Their Protection Measures," vol. 4, no. 4, 2018.

[7] P. H. P. W. Shell and G. Supriyatno, "Searching for Forensic Evidence in a Compromised Virtual Web Server against SQL Injection Attacks," vol. 12, no. 12, pp. 1057-1063, 2018.

[8] T. A. Cahyanto, V. Wahanggara, and D. Ramadana, "Analisis dan Deteksi Malware Menggunakan Metode Malware Analisis Dinamis dan Malware Analisis Statis," pp. 19-30.

[9] N. I. Widiastuti and M. Iqbal, "Basic Static Code Analysis Untuk Mendeteksi Backdoor Shell Pada Web Server," J. INFOTEL, vol. 9, no. 2, p. 177, 2017, doi: 10.20895/infotel.v9i2.209.

[10] T. Wijayanto, A. Susilo, T. Wijayanto, and A. Susilo, "Implementasi Backdoor Scanner Tool Menggunakan Metode Carving File Pada Server Codepolitan," pp. 141-148, 2017.

[11] O. W. Purbo, Keamanan Jaringan. Jakarta, 2011.

[12] M. Universitas, B. Darma, D. Universitas, B. Darma, J. A. Yani, and N. Plaju, "Analisis Pendeteksian dan Pencegahan Serangan Backdoor Pada Layanan," no. 12, pp. 1-10.

[13] Ali Mahmudi, "Sistem keamanan jaringan mendeteksi backdooruntuk menemukan celah dan exploitspada web server menggunakan teknik IDS (Intrusion Detection System), "Simki-Techsin, vol. 01, no. 04, pp. 1-10, 2017, [Online]. Available: http://simki.unpkediri.ac.id/detail/13.1.03.02.0003.

[14] H. Alnabulsi, "Textual Manipulation for SQL Injection Attacks," pp. 26-33, 2014, doi: 10.5815/ijcnis.2014.01.04.

[15] J. Komputasi, "Pembangunan Sistem Operasi Berbasis Linux Menggunakan Metode Linux From 
Scratch," vol. 1, no. 2, pp. 30-37, 2014.

[16] T. M. Aji, D. E. Riyanto, and H. A. Wibawa, "Penerapan web services dan regular expression untuk verifikasi alamat berbasis hasil penelusuran," vol. 1, no. 1, pp. 38-51, 2012. 